\title{
ПСИХОЛОГО-ПЕДАГОГІЧНІ ЗАСАДИ ФОРМУВАННЯ ПРЕДМЕТНИХ КОМПЕТЕНТНОСТЕЙ УЧНІВ ОСНОВНОЇ ШКОЛИ НА ОСНОВІ АКТУАЛІЗАЦІЇ ОБРАЗНОГО МИСЛЕННЯ ПІД ЧАС ВИВЧЕННЯ ХУДОЖНЬОЇ ЛІТЕРАТУРИ
}

Паламар С. П. Психолого-педагогічні засади формування предметних компетентностей учнів основної школи на основі актуалізації образного мислення під час вивчення художньої літератури.

У статті здійснено спробу розкрити психолого-педагогічні засади формування предметних компетентностей учнів основної школи на основі актуалізації образного мислення під час вивчення художньої літератури. Розкрито сутність процесу формування образного мислення учнів основної школи. Обгрунтовано поетапність формування предметних компетентностей учнів основної школи у процесі вивчення предметів гуманітарного циклу.

Ключові слова: психолого-педагогічні засади, предметні компетентності, учні основної школи, актуалізація образного мислення.

Паламар С. П. Психолого-педагогические основы формирования предметных компетентностей учащихся основной школы на основании актуализации образного мышления во время изучения художественной литературы.

В статье сделана попытка раскрыть психолого-педагогические основы формирования предметных компетентностей учеников основной школы на основании актуализации образного мышления в процессе изучения художественной литературы. Раскрыта сущность процесса формирования образного мышления учеников основной школы. Обоснована поетапность формирования предметных компетентностей учеников основной школы в процессе изучения предметов гуманитарного цикла.

Ключевые слова: психолого-педагогические основы, предметные компетентности, ученики основной школы, актуализация образного мышления.

Palamar S. P. Psychological-pedagogical basics of subject competence primary school students based on updating imaginative thinking while studying fiction.

The article is an attempt to reveal the psychological and pedagogical basis for the formation of subject competence primary school pupils on the basis of actualization of creative thinking in the study of literature. The essence of the process of formation of creative thinking of students of basic school. Substantiated poetapnost formation of subject competencies of basic school pupils in the process of studying the humanities.

Key words: psychological and pedagogical basis, subject expertise, primary school pupils, actualization of creative thinking.

Компетентнісний підхід до навчання учнів основної школи предметів гуманітарного циклу уможливлює формування предметних компетентностей на основі актуалізації образного мислення літературно спрямованої особистості, оскільки у такий спосіб сприяє розвиткові літературного творчого мислення.

Дослідження в галузі психології творчості (М. Арнаудов, Д. Кирнос, О. Никифорова, Я. Пономарьов, В. Роменець, Г. Тарасов, П. Якобсон, О. Яковлєва та ін.) дозволяють констатувати той факт, що досягнення високих творчих результатів пов'язані безпосередньо з виявом певних особливостей мислення особистості, отже, його нешаблонністю, нестандартністю, оригінальністю. На цьому наголошували в своїх працях Л. Ітельсон, С. Рубінштейн; В. Дружинін, Д. Кирнос, О. Матюшкін, Я. Пономарьов, В. Чистякова, Є. Яковлєва; Дж. Гілфорд, Г. Сієрвальд та ін.

Мистецтво, будучи засобом збереження і передавання раціонального й емоційного досвіду людства, вимагає від індивіда високого рівня сформованості образного мислення, завдяки якому він здатний не тільки розуміти художні образи, а й створювати їхню нову якість.

У педагогічній практиці проблема формування предметних компетентностей на основі актуалізації образного мислення учнів засобами літератури знаходить своє відображення, однак недостатньо грунтовно розроблену педагогічну технологію іiї розв'язання. 
Методичний аспект проблеми формування творчої особистості порушується і в роботах сучасних методистів. Заслуговують на увагу дослідження питання розвитку літературнотворчих здібностей Н. Волошиної, Б. Степанишина, В. Цимбалюка, В.Ягункової, які звертають особливу увагу на творчу діяльність учнів на уроках літератури, активізацію їхнього самостійного образного мислення.

На важливості розвитку оригінального образного мислення в учнів у процесі вивчення літератури шляхом проблемного навчання наголошують Г. Калиниченко, М. Кириченко, Н. Осташинський, В. Орлов, Т. Панько, О. Перун, Л. Піскорська, О. Прокопчук, В. Фещак.

Мета статmi - розкрити психолого-педагогічні засади формування предметних компетентностей учнів основної школи на основі актуалізації образного мислення під час вивчення художньої літератури.

Літературна творчість - психологічно напружена і непередбачувана за своїм результатом діяльність, що корелює з мистецтвом слова, шлях до пізнання якого такий же складний, як i шлях творення його нової якості, тому процес, який передбачає подібне новотворення, є складним у плані постійної потреби пізнання індивідом людського буття, краси світу (О. Білецький, М. Блінова, Л. Виготський, Г. Костюк, Е. Назайкинський, О. Нікіфорова, Г. Тарасов, Б. Теплов, П. Якобсон).

Відомо, що найвищим ступенем пізнання й освоєння світу є мислення - процес, пов'язаний 3 активним відбором інформації та ії̈ обробленням.

Мистецтво ж за своєю природою - результат образного мислення, основною функцією якого $є$ створення нових образів, відмінних від попередніх. Отже, поняття «образне мислення» наділяється ще й функцією вияву якісного боку художнього образу, що є основним продуктом художньої літературної творчості і здатний естетично впливати на людину. За визначенням Л. Ітельсона, образне мислення відображає суттєві зв'язки дійсності специфічним способом втілюючи їх у русі і змінюванні образів-уявлень [7].

Основоположним у цьому перетворенні має бути не наочність художнього образу, а його виразність, яка б викликала в людини не тільки переживання, а й роздуми, що становить сутність образного (за С. Рубінштейном) художнього мислення [10, с. 26-27].

Цілісно вияв образного мислення може бути досягнутим тільки за умови максимальної активізації мисленнєвого процесу людини, що можливо саме в ситуації творчості.

Внутрішня форма художнього твору - це той його рівень, який вбирає в себе сукупність засобів предметного зображення у творі, на відміну від рівня словесного зображення (сукупності словесних прийомів) та структурно-організуючого рівня - композиції, що зв'язує в єдину цілість усі рівні форми твору та їхні окремі компоненти.

У художньому творі цей рівень форми постає у вигляді динамічної картини зображуваного життя, даної з усіма ії індивідуальними подробицями - образами твору, що, розгортаючись у ньому, певним чином між собою взаємодіють.

Структура внутрішньої форми твору включає систему образів й динамічну послідовність їх розгортання у творі, яку називають сюжетом.

Загальноприйнятим у сучасному літературознавстві $\epsilon$ визначення художнього образу, яке дав у свій час Л. Тимофєєв: «Образ - це конкретна і водночас узагальнена картина людського життя, що створена за допомогою вимислу й має естетичне значення» $[11$, с. 60$]$.

Наведене визначення як таке, що відображає естетичну сутність художнього образу, Л. Тимофєєв протиставляє широковживаному, але термінологічно не конкретизованому визначенню образу як узагальненого відображення дійсності у формі одиничного, індивідуального.

В основі художнього образу як специфічної форми відображення дійсності лежить первинний, або так званий чуттєвий образ. Від повсякденних форм уявлення дійсності художній образ, по-перше, відрізняється своєю емоційністю, точніше настановою на підкреслено-емоційний характер вираження тієї думки, формою вияву якої є чуттєвий образ. По-друге, від звичайного уявлення художній образ різниться узагальненістю свого змісту.

У мистецтві художній образ цінний не сам по собі, не як пряме і максимально повне відображення дійсності, а тією мірою, якою він здатний уособлювати собою якийсь більш загальний, ніж конкретно-фактологічний, зміст. 
Художній образ як специфічна форма відображення дійсності відрізняється не лише від повсякденних уявлень, а й тісї форми вираження світу, якою користується наука, а саме поняттєвою, оскільки відтворює його засобом конкретно-чуттєвої основи.

Міра суб'єктивності, хоча й завжди наявна в художньому образі, може бути в ньому більшою або меншою залежно від способу світосприйняття митця й тих художніх принципів, які він сповідує.

Загальна структура образу в усіх видах мистецтва виходить 3 його двокомпонентної будови, поєднання в ньому чуттєвого образу й ідеї, яка з цього останнього випливає.

Суттєвою відмінною ознакою літературно-художнього образу $\epsilon$ те, що він дає не статичний, як, наприклад, у живописі, а динамічний образ дійсності, який розгортається в системі своєрідних взаємовідображень тих форм зображення, що конкретизують його: діалоги, монологи, авторські роздуми й описи, картини природи тощо.

Літературно-художній текст, реалізований у системі образів, характеризується образністю. Образність художнього тексту є втіленням емоціонального осмислення пізнання світу митцем. Досконале відтворення картин й образів викликає естетичні почуття у читача. Художнє мистецтво виконує не лише естетичну (формування творчого духу й ціннісних орієнтацій), а й рекреативну, світоглядну, пізнавально-евристичну, художньо-концептуальну, компенсаторну та сугестивні функції [5, с. 132-150].

Уміння викликати естетичні почуття у читача є насамперед умінням відчувати автором широкий діапазон кольорових, звукових і пластичних вражень, їх кодувати у мовних знаках, втілювати в них ідеї. Естетичне почуття - це фундамент естетичної свідомості людини. Естетична емоція є найвищим етапом розвитку людської чуттєвості і характеризується не тільки як реакція організму на зовнішні подразники, що відрізняються гармонією, досконалістю, цілісністю й упорядкованістю; вона є реакцією людини, що освоїла й освоює параметри об'єктивного світу й соціуму. По суті естетична емоція є емоціональною реакцією, що відображає рівень і характер духовного життя людини, взаємопов'язаний з уявленнями людей про бажане й прекрасне як у теперішньому, так і в майбутньому. Естетична пам'ять $\epsilon$ також інформативною емоціональною пам'яттю, що в результаті трансформує людину, яка стає більш чутливою, сприйнятливою до естетико-емоціонально впливових об'єктів і явищ. Через естетичні почуття для людини стають особистісно значущими й конкретними ідеї морального обов'язку, патріотизму, людяності, набувають змісту категорії етики й естетики.

Образність як критерій розмежування реалістичності і символічності в системі образів дозволяє в розумінні художнього образу як форми відображення світу окремі його види визначати залежно від типу змістового узагальнення, даного в художньому образі, або, інакше кажучи, за типом смислового співвідношення між чуттєвим образом та його ідеєю [5, с. 103-104]:

1. Автологічний тип художнього образу.

У структурі автологічного художнього образу чуттєвий образ є формою вияву такої ідеї, яка, певним чином розширюючи й узагальнюючи зміст одиничного предмета, у ньому змальованого, не виходить за його межі, тобто не вказує на жодний інший, якісно відмінний від нього предмет.

У визначенні автологічного образу як самозначущого міститься певна частка умовності, оскільки самозначущий художній образ не є носієм лише буквального змісту: він $є$ засобом узагальнення, мета якого полягає в організації естетичного впливу через свого роду «ефект упізнавання».

Самозначущий образ - це образ, який фіксує якісь типові, характерні, найбільш суттєві (в естетичному відношенні) аспекти зображуваного.

Типовий образ об’єднує в собі ознаки, спільні для більшої кількості однорідних предметів; вибрані для зображення такого предмета спільні риси й ознаки називаються типовими або характерними. Типово можуть бути зображеними особи або речі, а також явища та події, взаємовідношення між людьми, їх звички і заняття, обставини місця і часу, природи тощо. Але найважливіше значення в художньому мистецтві мають типи людей, тобто дійових осіб, виведених в якімсь творі» [6, с. 7-8].

2. Металогічний тип художнього образу.

У структурі металогічного художнього образу чуттєвий образ є формою вияву такої ідеї, яка, узагальнюючи зміст одиничного предмета, у нього змальовуваного, виходить за його межі 
і вказує на якийсь інший, якісно відмінний від нього предмет. Чуттєвий образ та ідея належать до різного кола явищ. До групи металогічних образів відносять символ, алегорію та підтекст.

Найяскравішим виявом металогічного образу є символ.

Символічного значення художній образ набуває за умов: 1. Коли зображуваний автором предмет сам по собі є символом: йдеться про традиційну символіку, усталені образи-символи, які органічно закріпилися за певними, в основному природними об'єктами, в суттєвих ознаках яких вбачали певні аналогії з ціннісними виявами людського життя (життя / шлях; пори року / вік людини; хмари / нещастя тощо). 2. Зображуване може стати символом, передбачає, що предмет, який зображується, сам по собі не є символом, або є ослабленим, «призабутим» символом. Більш-менш чітко виражених символічних ознак він набуває безпосередньо в процесі самого зображення. Такі символи називають індивідуально-авторськими, тобто такими, що з'являються поза загальною традицією (чи поновлюють ії призабутий зміст) і $є$ наслідком авторської настанови на узагальнення й поглиблення смислової перспективи того чи іншого зображуваного об'єкта.

Матеріальними носіями символу в художньому творі можуть бути: метафори, пейзажі, художні деталі, персонажі тощо.

Найбільш уживаними в системі образів є образи ліричного героя (образ автора) й пейзаж.

Пейзажем називається образ природного оточення персонажів та їхніх дій, опис картин природи в художньому творі, який має певне значення в його загальній змістовій організації. Найважливіша функція пейзажу полягає в тому, що він $\epsilon$ у творі як додатковим опосередкованим засобом характеристики окреслюваних у ньому героїв, персонажів.

Змістовий обсяг поняття «пейзаж» не вичерпується його допоміжною функцією як одного iз засобів художнього втілення персонажа $\mathrm{i}$, разом з тим, $\epsilon$ в плані художнього змалювання персонажів літературного твору принципово важливим.

Як правило, відношення пейзаж - людина в художньому творі будується на принципах так званого психологічного паралелізму - контрастного протиставлення, або зіставлення картин природи з душевним станом, емоційним людини.

Ліричний герой (образ автора) становить специфічного розповідача, в особі якого знаходить свій вияв підкреслена співвіднесеність з авторським «я», що стало простежується в межах більш-менш значної групи ліричних творів певного тематичного циклу, біографічного періоду або й творчості окремих поетів загалом.

Ліричний герой становить поетизовану суть авторського «я», котра найповніше відповідає його естетичному ідеалові, це той літературний характер і та поетична біографія, яку художньо конструює автор для своїх читачів.

Система образів природного оточення й ліричного героя (образа автора) найбільш повно відтворює сюжетну лінію й художню мету твору.

На думку відомого вітчизняного психолога Л.Виготського [4], акт мистецтва як результат складної психічної діяльності включає в себе такі акти мисленнєвого процесу, як: раціональне пізнання, розуміння, розпізнавання, асоціативність.

Отже, пізнаючи світ, природу людини, митець намагається зрозуміти його, освоїти, щоб потім шляхом власного перетворення явити іншим в новій якіснішій іпостасі. Відповідно до способу такого перетворення відрізняють індивідуальну манеру, стиль митця.

Спробуємо теоретично осмислити природу процесу образного мислення задля подальшого аналізу проблеми нашого дослідження - формуванн предметних компетентностей учнів основної школи у процесі навчання предметів гуманітарного циклу.

У фізіології та психології знаходимо пояснення щодо цього: єдиними каналами, через які до людської свідомості надходить інформація про довколишній світ, є органи чуття - зору, слуху, смаку, нюху, дотику.

Зазначимо, що творчість майстра слова особливо чутлива до зорового враження, хоча спостереження над художніми творами свідчать про важливість кожного 3 них. «Відчувати і сприймати, помічати і невтомно збирати враження, - пише М. Арнаудов, - основна риса творчої особистості і важлива передумова того багатства образів, яким відрізняється всякий значний художній твір» [1, с. 55].

Отже, мисленнєвий процес безпосередньо пов'язаний з емоційним самопочуттям суб'єкта. Природа таких емоцій $є$ загальною емпатійною настановою у ставленні до мистецтва (як 
естетичної форми об'єкта), тобто готовність індивіда перенести суб'єктивний зміст (почуття) в об'єкт і відчути його в ньому, або ж створити в суб'єкті таку психічну настанову, яка була б здатна протистояти силі впливу об'єкта $[4 ; 10]$.

Провідними мотивами творчості є необхідність пізнання і естетичні потреби, а також середовище, що підтримує творчі ідеї. У статтях про специфіку літературної творчості П. Білоус називає такі мотиви, як самовираження, пізнання (самопізнання), змагання (суперництво), волю до влади, витіснення психічних комплексів, гедонімізм (насолоду), народження, втечу від дійсності, медитацію та спробу увічнити себе [2, с. 3-5].

Важливу роль внутрішній мотивації, без якої неможливо досягти успішного результату у творчості, надавали у своїх психолого-педагогічних працях науковці Д. Кирнос, В. Крутецький, О. Леонтьєв, О. Лук, О. Нікіфорова, В. Чудновський, П. Якобсон та ін.

У дослідженні проблеми формування предметних компентностей унів основної школи на основі актуалізації образного мислення спираємося на думку Б. Ітельсона, який стверджує, що мислення запускається трьома основними типами стимулів [7, с. 306-310]: 1. Внутрішні стимули, тобто емоції і потреби індивіда, завдяки яким мислення спрямовується на пошук шляхів способів та результатів їх задоволення. 2. Зміст і спрямованість образного мислення керуються завданнями спілкування, тобто освоєння певної інформації відбувається ззовні, якот через слово чи ілюстрацію, що вимагає відтворюючої діяльності уяви. 3. Важливим стимулом $є$ той, коли образне мислення викликається завданнями діяльності й залежить від них $[7$, c. 310]

Водночас внутрішнє (чуття) зумовлене зовнішнім впливом. Афекти збудження такі, як гнів, захоплення, страх, стурбованість, перевищуючи міру терплячості митця, шукають «вихід у творчість» [12, с. 189]. Реакція чуттів безпосередньо зумовлює формування образу - спочатку словесного як символу, на наступному етапі - художнього.

Словесний образ є найуніверсальнішим символом, структурно-інформаційною одиницею людської пам'яті і мислення, кодом певної інформації. Маючи зовнішню форму (єдність звуків), суть поняття (оформлене в слово) та образ понять (внутрішнє значення) словесний образ може мати подвійну художню силу - як засіб вираження естетичного і понятійного. На цю подвійність указували О. Лук, О. Потебня, С. Рубінштейн, К. Ушинський.

Будучи основою образного мислення, уява і фантазія відіграють у цьому процесі головну роль. Якщо уява репродукує попередньо набуту інформацію, в чому неабияке значення має пам’ять, то фантазія отримує від неї цю інформацію для комбінаційної роботи.

Безперервно порівнюючи одні предмети 3 іншими, попередній запас знань із новим явищем, людина експериментує, визначаючи тим самим запас міцності матеріалу, його опір, якість. Отже, органічною властивістю людського мислення, важливим механізмом художнього образу є метафорична рецепція довкілля, яка будується на порівнянні / зіставленні. Порівняння ж О. Квятковський називає «початковою стадією, звідки у вигляді градації та розгалуження виходять майже всі інші тропи» [8, с. 280].

Отже, образне мислення в літературній творчості неможливе без високорозвиненої системи тропів, «вони є суттю» його, «сфера їх навіть $є$ ширшою, ніж мистецтво» [9, с. 25-33]. Варто розглянути питання використання тих способів у літературній творчості, передумовою створення яким слугують такі найхарактерніші риси літературно-творчих здібностей особистості, як: спостережливість у баченні світу, розвинута уява, пам'ять, фантазія, розкутість асоціацій, інтуїція, гнучкість мислення.

Суттєву роль в умінні доповнювати відіграє життєвий і творчий досвід індивіда. Нові задуми, ідеї потребують і творчого підходу до їх реалізації саме через удосконалення техніки, a, отже, прийомів і способів перетворення уже відомого, оскільки усталений поетапний процес мисленнєвої діяльності автоматизує іiі, стереотипізує. Оволодіння ж новими технічними засобами створює і нові творчі можливості. Тому в контексті нашої роботи суттєвою є думка С. Рубінштейна, що сприймання художника у своїй художній специфічності почасти зумовлюється технікою художнього зображення. Зокрема, психолог презентує такі три основні прийоми перетворення дійсності з допомогою уяви: а) комбінування (співвідношення даних в досвіді елементів у нових); б) акцентуація (навмисне підкреслення рис, яке досягається завдяки зміні пропорцій, певних зсувів, отже, шляхом применшення (літоти) чи перебільшення 
(гіперболи)); в) типізація (специфічне узагальнення, у результаті якого образ уяви $є$ наочним образним носієм усвідомленого задуму).

Оскільки літературна творчість послуговується перетворювальною діяльністю уяви, фантазії, то вони і є основою творчого процесу, оскільки він найбільше виявляє себе в період «руху образної думки» [3, с. 2-3] від народження ідеї і до моменту її реалізації.

У психологічній думці відомою $є$ ідея щодо чотирьох етапів творчого акту: підготовка, інкубація, відкриття, завершення. Зокрема Є. Артем'єва, О. Білецький, Г. Буш, А. Ковальов, О. Кульчицька, В. Левін, Б. Лейзін, В. Моляко, В. Роменець, П. Якобсон та ін. вказують на певну етапність - це усвідомлення проблеми, іiі розв'язання та перевірка. В процесі літературно-художньої творчості, як правило, виокремлюють теж три етапи: задум, перетворення задуму в обдуманий план, втілення плану в матеріальну форму.

Основним актом творчості здебільшого відповідають і основні компоненти продукту, в цьому випадку художнього твору: ідея, тема, сюжет, композиція, система тропів. Слід зазначити і те, що художній образ перебуває в тісному взаємозв'язку з обома етапами творчого акту, оскільки часто $є$ цілісним схопленням задуму-ідеї, її мистецьким втіленням.

Дослідження природи образного мислення в контексті літературно-творчого процесу дозволяє ствердити, що:

-літературна творчість - складна психічна діяльність, сукупність актів мистецтва, супроводжувана процесом мислення в образах задля знаходження нових, якісних змістів художнього відтворення дійсності;

-образне мислення реалізується за умови свідомої спрямованості людини на творчий мислительний процес, поетапному здійсненню якого передує збагачення раціональним та чуттєвим досвідом індивіда;

-продуктивність мислительного процесу в образах залежить від уміння митцем знаходити способи перетворення наявного в бажане - таке, що не зустрічалося в художньому змісті людського пізнання.

Отже, стуктура літературно-творчих здібностей основної школи (глибокий інтерес до літератури, свідоме творче ставлення до розв'язання проблем літературного характеру та накопичення знань у цій галузі, багатство почуттів, поетичне сприймання та відчуття світу) сприяє накопиченню досвіду образного мислення та можливість його реалізовувати в оригінальному продукті, що відіграє вирішальну роль в актуалізації образного мислення, забезпечуючи ефективне формування предметних компетентностей у процесі вивчення предметів гуманітарного циклу.

\section{Література}

1. Арнаудов М. Психология литературного творчества / М. Арнаудов. - М. : Прогресс, 1970. С. 17. 2. Білоус П. В. Таємничі джерела художнього мислення / П. В. Білоус // Украӥнська мова і література: Шкільний світ. - К.- 2000. -№ 5. - С. 2. 3 Волошина Н. Й. Виховання учить засобами художнього слова / Н. Й. Волошина // Зарубіжна література в навчальних закладах. - 1996. - №7. С.2-5. 4. Выготский Л С. Психология искусства / Л. С. Выготский. - М.: Педагогика, 1987. - 344 с. 5. Галич О. Теорія літератури : [підручник] / за наук. ред. Олександра Галича. - К. : Либідь, 2006. 488 с. 6. Домбровський В. Українська стилістика і ритміка. Українська поетика / В. Домбровський. К. : Либідь, 1993. - 231 с. 7. Ительсон Л. Б. Лекции по общей психологии / Л.Б. Ительсон. - [2-е изд.]. - Владимир, 1972. - 595 с. 8. Квятковский А. П. Поэтический словарь / А. П. Квятковский. М. : Сов.энцикл., 1966. - С. 280. 9. Коцюбинська М. Х. Відтворення чи перетворення (до генезис метафоричного образу) / М. Х. Коцюбинська // Радянське літературознавство. - 1967. - № 1. - С. 2533. 10. Рубинштейн С. Л. О мышлении и путях его исследования / С.Л. Рубинштейн. - М., 1958. С.26-27. 11. Тимофеев Л. И. Основы теории литературы / Л. И. Тимофеев. - М., 1976. - 234 с. 12. Чистякова Г. Д. Творческая одаренность в развитии познавательных структур / Г. Д. Чистякова // Вопросы психологии. - 1991. - №6. - С.103-11. 13. Якобсон П. М. Психология художественного творчества / П. М. Якобсон. - М.: Знание. - 1971. - С. 7. 